\title{
The Role of Muhammadiyah in the Development of Social Capital Community
}

\author{
Sri Iswati, Sri Herianingrum, Muslich Anshori, Effendie, Tika Widiastuti, Ririn Tri Ratnasari \\ Postgraduate School \\ Universitas Airlangga \\ Surabaya, Indonesia \\ iswati.feua@gmail.com \\ sri.herianingrum@feb.unair.ac.id \\ slich@unair.ac.id \\ effendie.unair@gmail.com \\ widasus@yahoo.com \\ ri.ratnasari@gmail.com
}

\begin{abstract}
The Muhammadiyah institution is not just a religious social institution, but it is the axis of civilization for Muslims. It become one of the hearts of important Muslim activities in Indonesia, not only as a religious social institution, but also as a centre of da'wah, schools and other important agendas related to the ummah. Along with the increasing understanding of Islamic society in Indonesia, the existence of Muhammdiyah institutions as an institution is needed for Muslims, because it not only focuses on religious activities, but also develops by intensifying social activities and economics such as elementary education institutions through to universities, hospitals, cooperatives and baitul maal wa tamwil. All of the activities of the programs will encourage the formation of social capital, which will assist in realising the brilliance of Islamic civilization and reaching falah. The research method used in this research study was a descriptive qualitative approach with a case study method. Based on the data and analysis that has been done, it can be concluded that the Muhammadiyah institution has an active role in developing the social capital surrounding communities. This is evident from the management efforts in applying said management, thus making Muhammadiyah as a solute institution when it comes to serving the community. One element of social capital that has begun to grow in the community is the formation of networks.
\end{abstract}

Keywords—Social Capital; Muhammadiyah Institution; Network.

\section{INTRODUCTION}

For Muslims in Indonesia, the Muhammadiyah institution is a very popular institution. The Muhammadiyah institution is not just a religious social institution. The Muhammadiyah Institute is the axis of civilization for Muslims. The Muhammadiyah institution has become one of the hearts of important Muslim activities in Indonesia, not only as a religious social institution, but also as a centre for da'wah, schools, and other important agendas related to the ummah.

Along with the increasing understanding of Islamic society in Indonesia that has occurred, the existence of the Muhammdiyah institution as an institution is needed for Muslims, because it not only focuses on religious activities, but also develops by intensifying the social activities as well as economics such as elementary education institutions through to universities, hospitals, cooperatives, baitul maal wa tamwil, and so on. All of the activities of these programs will encourage the formation of social capital, which will assist in realising the brilliance of Islamic civilization and reaching falah.

Capital as has been widely understood consists of natural capital, human capital, and physical capital. There is one more capital that is very important for the sustainability of development, namely social capital. The success of a nation's development depends on the availability of the aforementioned four elements of capital. Therefore, building and developing social capital has become one of the most important aspects involved besides the formation of the other capital.

According to Putnam (1993) in Haridison (2013: p.32) social capital is a collection of horizontal associations among people who have an influence on the productivity of the local community. Fukuyama (1999: p.22) defines social capital as a set of shared values or informal norms among the members of a group that allows for cooperation between them. From the above, it can be understood that the definition of social capital is a set of values or norms that enables people to work together in achieving common goals. Razmi et al (2013: p.3) stated that the result of low levels of social capital such as a lack of public trust, efficient communication networks, and the absence of effective norms leads to problems such as unwillingness to do with social co-operation and the absence of social unity and cohesion which could be a hindrance towards human development. The development of social capital becomes very important considering that people now are really in need of a tool in development and empowerment.

Fukuyama assumes that religion is a source of abundant social capital and that religious organisations are the most effective organisations for creating values and morals. Religion is a source of great moral behavior, then the decline of religion in the face of modernisation means the end of social order (Fukuyama, 1999: p.404). The existence and guarding of religion is very important in the order of community life. Islam as a syumul religion and universally has provided life guidelines that can be used throughout a human's life. The concepts in social capital are in fact a concept that already exists in the Al-Qur'an and As-Sunnah. Social capital in Islam aims to create human prosperity in the dimension of the world and the hereafter. 
Based on the above background, the formulation of the problem in this research is, "what is the role of Muhammadiyah institutions in developing social capital around society?' The benefits of this research can be used as constructive input for Islamic institutions, ministries of religion and central government. This study is limited to Islamic institutions in order to be more focused in the discussion, assuming that Islamic institutions are the most prominent focus that can be explored.

\section{STUDY Literature}

\section{A. Social Capital in Islam}

When the term social capital became known in the $19^{\text {th }}$ century, Islam had previously provided the concept of social capital when the Al-Qur'an was revealed to the Prophet Muhammad SAW. Allah, through the Al-Qur'an, provides guidance on humans living in his role as a servant of Allah and the caliph on earth. In addition, Al-Hadits or As-Sunnah of the Prophet became the second guideline for human beings in running various Islamic Shari'a sects. From these explanations, it is clear that Islam has a strong foundation in developing social capital.

According to Minarti (2003) in Wahyuningsih (2016:47), Islam is committed to social contracts and norms that have been mutually agreed upon, and the building of the Muslim community is essentially ta'awun (mutual help), takaful (mutual bear), and tadhomun (having solidarity). This attitude in Islam is often called the concept of ukhuwah islamiyah (brotherhood among Muslims). When we look in the AlQur'an, there are verses that encourage people to always build good relationships among their fellow human beings. The verse contains a command to help each other with deliberation, cooperation, trust, honesty, respect for their parents, etc. The bond of ukhuwah Islamiyah is a strong foundation for social capital building, and can be a adhesive for the community so that they can work together and unite in achieving common goals, including economic development (Sanrego and Taufik, 2016: p.138).

At the beginning of the decline of Islam, Rasulullah exemplified how he built Medina and his society into a civil society. Medina, at that time, became the centre of Islamic civilization. Both Muslims and non-Muslims living in Medina can walk in harmony, and uphold moral of goodness. Medina society also has good social order, and balances the rights and obligations of individuals and communities.

For Muslims, Islam is a straight, clean and peaceful religion. Islam always encourages people to be honest, to help each other, to trust each other, to remind each other in kindness, and to build good network with their fellow human beings. Islam also encourages its people to cooperate when solving various problems together so that Islam can be a religion of rahmatan lil alamin. Hasbullah (2006:95) stated that "striving, working, hospitality, interacting and working together is a fire of burning Islamic social capital".
Islam is a religion that encourages human development, so the teachings contained in it are none other than to form the best people or khoirul ummah. If Islamic values develop in the life of society, there will be no prosperous villages, orphaned orphans will not exist, there will be no corruption, and there will be no people molesting each other (Hasbullah, 2006:95). This is in harmony with what has been expressed by Farooqi (2006:3); "the social meaning of Islamic social welfare system". In other words, social capital in Islam is a collection of values, norms, and networks in accordance with Islamic shari'ah, which grows from the foundation of ukhuwah Islamiyah which can encourage people to prosper in the world and in the hereafter, and to form a good ummah (khoirul ummah).

\section{B. Maqashid Syariah}

The language of maqashid syariah consists of two words namely maqashid and syariah. Maqashid means deliberate or purpose which is the plural form of maqsud derived from the qashada syllable meaning to mean. Maqashid means the things desired and intended (al-Afriqi, without years: p.175). Syariah language means the way to the source of water, and the way to the source of water can also mean walking towards the source of life (Rahman, 1994: p.140).

Maqashid syariah contains a general and a special understanding. The general notion refers to what is meant by the legal verses or legal hadith, whether are either expressed or implied. The notion of a general nature is synonymous with the definition of the term maqashid as-syari' (Allah in decreasing the verse of the law or the Rasulullah in issuing hadith law). The meaning of a special nature is the substance or purpose to be achieved by a legal formula.

Many theories assess the empowerment of society. One of the indicators to measure community empowerment is the welfare of society itself. One of them is the Human Development Index (HDI). With regards to HDI, UNDP describes three indicators for measuring the education, health, and purchasing power of the community. It means that the high level of people's welfare depends on these three things. If most are fulfilled from the three, then the level of prosperity in the country is quite high (Surullah, 2013:40).

Welfare indicators based on HDI according to Zadjuli (2006) do not include all of the components required in the framework of welfare in Islam. A holistic Islamic economic system is offered to answer the question, with the following functions:

1. Fighting against stupidity. The stupid sense has been likened to someone who is not good at reading, writing and counting. Islam teaches that the ignorant are also the unreasonable. The unreasonable are the people who do not function well, those who worship and fear any other than Allah. If a man has obtained a professorship or doctor's degree in various sciences, but worships and fears the idols made by man himself, or worships the wood, stones and 
animals of a lower rank than what is human, then that is as foolish, both in the world and in the hereafter. So a person who cannot read, write, and count but worships and does charity following sunnatullah can be categorised as a smart person in the world and in the hereafter.

2. Fighting against poverty. The notion of the rich is someone with a lot of possessions in the form of money, vehicles, land, houses, stocks, etc. Conversely, if the individual does not have those things, they are categorised as a poor person. Islam teaches that the rich are when most of the sustenance earned is a deposit from Allah, and in turn has been given to asnaf in need.That is: the poor, the one who has run out of supplies on the way, the debt-wracked, the convert, the slave, fisabilillah, and amil zakat when needed.

3. Fighting against the pain. Many sick people are in hospital or at home where Allah has discharged the disease and provides medicine. The person depends on himself or their family to heal from the sickness. The real pain is the difficulty in treating the people who have closed or locked eyes, ears, heart, and mind as written in the surah of AlBaqarah verse 7 .

4. Fighting against falsehood. Islam has shown the righteous and true path, but many people are caught up in falsehood in order to fulfil their daily lives because they have been poisoned by secularism that desperately desires lusting for possessing as much wealth as possible or seeking the highest possible position in any manner. Humans must be clever to manage their brain or mind, because eventually the human brain can manage the lust as outlined by the human conscience itself.

From the above opinion, it is known that welfare indicators according to Zadjuli (2006) are not as defined by the United Nations Development Programs (UNDP) in relation to the Human Development Index (HDI) indicating life expectancy, education, and purchasing power. Zadjuli added one more indicator of justice, thus the welfare indicator according to Zadjuli (2006) becomes intelligence, wealth, health and justice. According Kesi, community empowerment can be measured through the ability of the community in utilising business for the future.

\section{RESEARCH METHODOLOGY}

\section{A. Research Approach}

This study used a qualitative approach, namely research methods that examine a natural phenomenon in which the author becomes a key instrument. This qualitative research has been directed specifically towards the use of case study methods. The case study method is appropriate for this research because it is the best choice to answer the problem formulation of this research, which is how the role of the Muhammadiyah institution in social capital development relates to society. This research topic is a phenomenon of social capital development today through community institutions, and researchers have no chance to control what has happened and is happening within the institution.

\section{B. The scope of research}

The problem formulation in this research is the role of the Muhammadiyah institution in developing social capital in the maqashid syariah perspective. The formulation of the problem can become the reference of researchers in determining the scope of the study, which can be used as a reference with the limitations or scope of this study focused on the program of Muhammadiyah institutions in the development of social capital in the community. The object of research used in this research is the leader of the Muhammadiyah Institute.

\section{DISCUSSION OF THE RESULTS}

The Muhammadiyah organisation is an Islamic movement, da'wah amar ma'ruf nahi munkar, and tajdid that is based on Islam and sourced from the Al-Qur'an and As-Sunnah. The concept of social capital in Islam has actually existed along with the decline of the Al-Qur'an as revealed to the Prophet Muhammad. Since the beginning of the arrival of Islam, things that concern social capital have been practiced by the Prophet Muhammad and the Muslims. One of the precepts of Islam that underlies the formation of social capital is the concept of ukhuwah islamiyah or brotherhood which is based on faith and Islam belief (Sanrego and Taufik, 2016:129).

One of the verses mentioning ukhuwah is in the QS. AlHujurat verse 10:

"The believers are but brethren, therefore make peace between your brethren and be careful of (your duty to) Allah that mercy may be had on you".

The pronunciation of "ikhwah" has the meaning of relatives in families with blood or descent-based relationships. In the above verse, Allah states that every believer is a brother to his neighbour. The brother in question is certainly not in the context of a blood relation, because Muslims are very numerous and spread over various parts of the world. The meaning of 'you' in that verse implies that all Muslims are like a family born from the same womb, that is in relation to faith and piety to Allah. The use of the word "ikhwah" in the verse shows the relationship of nearness and closeness between each believer (Sanrego and Taufik, 2016:135). The existence of ukhuwah shows that Islam encourages its followers to always do good, and to build good brotherly relationships with one another. This interweaving is a pillar for the formation of social capital.

The Muhammadiyah institution as an Islamic religious institution has great potential for improving ukhuwah Islamiyah as the foundation of social capital, especially in Indonesia where the majority of the population are Muslim. Ahmed (2009) in Sanrego and Taufik (2016) mentioned at least three important institutions that can foster productive social capital within the framework of Islam. The first is the role of community leaders, the second is the institution of religion such as Muhammadiyah as a producer of social capital in the surrounding community, and the third is the family entity that can produce a community of citizens. 
In accordance with the vision of the mission, the Muhammadiyah board of management has sought to make the institution a centre for community activities. This has been done by the implementation of programs and management in accordance with the needs of the people. The strict management of Islamic institutions in implementing the Sunnah has made it an attraction that will bring in many people who will go on to become members and follow its activities.

The formation of social capital starts from the formation of social structures in wider society. One of the best strategies to encourage the formation of a social structure is the interactions that occur within the community, which will generate social forces that can be used to overcome problems (Lawang, 2004:219). At this stage, Muhammadiyah has been playing its role by forming communities based on age segmentation, study groups and hobbies. Muhammadiyah in every study activity collects infaq, and the infaq will be channelled to people who have problems and need help. Through this process, social capital will grow within the community.

Social capital that has been formed in this way can be developed and must be maintained so as not to fade away. Communities are regularly gathered so that the Muhammadiyah functions in keeping the elements of social capital going, not just the network but maintaining the trust, value and norms of society. In this strategy, there are goals and targets to be achieved periodically, as well as the efforts required to achieve them that must also be ongoing. The attitude of the board is open to congregation and be able to provide solutions to the various problems around, which will increase the trust of the congregation of Muhammadiyah, and will encourage better cooperation between the congregation and the public or within the institution.

With regards to economic development, social capital is seen of as an important factor. Social capital is a factor that affects the economic health of a country, which relies on cultural roots (Fukuyama, 1995:49).

Sanrego and Taufik (2016:257) disclosed the link between social capital and economic performance:

"Social capital contributes to economic performance through their ability in real practice. Social capital maintains cooperation, fosters mutual trust (mutual norms) and reduces transaction costs involved in production and exchange. At the same time, production and the resulting exchange can lead to the accumulation of social capital".

The existence of the role of Muhammadiyah institutions in developing social capital will provide opportunities for good social relationships between the economic actors in the surrounding environment. Social capital also has the potential to improve the entrepreneurial spirit of the surrounding community, thereby helping to develop the business world. Enterprises will have the opportunity to grow faster when in the middle of a society that has good values and norms, high levels of trust, and a strong relationship within the dynamic network.

\section{Conclusions}

Based on the data and analysis that has been done, the Muhammadiyah institution has an active role in developing social capital in the surrounding communities. This is evident from the management efforts in applying management, thus making Muhammadiyah as a solute institution in serving the community. One element of social capital that has begun to grow in the community is the formation of networks.

\section{Acknowledgment}

Thank to Dr. Sri Herianingrum, S.E., M.Si., Prof. Dr. Muslich Anshori, SE. Ak., Prof. H. Effendie, SE, Dr. Tika Widiastuti, SE., Msi, Dr. Ririn Tri Ratnasari, SE., Msi for support, guidance and suggestions to make this research finished.

\section{References}

[1] Anshori, Muslich dan Sri Iswati. Buku Ajar Metodoloogi Penelitian Kuantitatif. Surabaya: Airlangga University Press, 2009.

[2] Ardiansyah, R. Dampak Keberadaan Masjid Terhadap Pemberdayaan Masyarakat Sekitar Pada Masjid Baitul Hikmah Gayungan dan Masjid Al-Hikmah Kebonsari di Kota Surabaya. Surabaya: Universitas Airlangga. Unpublished thesis, 2012.

[3] Brigaitis, P. Religious Engagement and Social Capital in the Islamic Context. University of North Texas, 2005.

[4] Bungin, M Burhan. Metodologi Penelitian Kualitatif. Jakarta:Kencana, 2007.

[5] Farooqi, A H. Islamic Socisal Capital and Networking. Emerald Insight, 113-125, 2006

[6] Felicio, dkk. 2014. Human Capital, Social Capital, and Organizational Performance. Humanomics hal. 350-364.

[7] Field, J. 2003. Modal Sosial. Yogyakarta: Kreasi Wacana. Penerjemah: Nurhadi.

[8] Fukuyama, F. 1995. Trust: Kebajikan Sosial dan Penciptaan Kemakmuran. Yogyakarta: Qalam.

[9] ---------. 2004. Memperkuat Negara: Tata Pemerintahan Dan Tata Dunia Abad 21. Jakarta: PT. Gramedia Pustaka. Penerjemah: A. Zaim Rofiqi.

[10] ----------. 1999. The Great Disruption: Hakikat Manusia dan Rekonstitusi Tatanan Sosial. Yogyakarta: Qalam. Penerjemah: Ruslani.

[11] Haridison, A. 2013. Modal Sosial dalam Pembangunan. JISPAR, hal. 31-40.

[12] Hasbullah, J. 2006. Social Capital: Menuju Keunggulan Budaya Manusia Indonesia. Jakarta: MR-United Press.

[13] Hasbullah \& Mahalli. 2004. Hadis-Hadis Muttafaq 'Alaih (Bagian Munakahat \& Mu'amalat). Jakarta: Prenada Media.

[14] Hasan, Abul. 2014. The Challenge in Poverty Alleviation: Role of Islamic Microfinance and Social Capital. Humanomics, Vol. 30 Issue: 1, pp.76-90

[15] BIBLIOGRAPHY 11033 Lawang, Robert M. Z. 2004. Kapital Sosial Dalam Perspektif Sosiologik: Suatu Pengantar. Depok: FISIP UI PRESS.

[16] Lewis, \& Garner. 2005. Antropologi, Pembangunan, dan Tantangan Pasca Modern. Maumere: Ledalero.

[17] Moleong, L. 1989. Meotode Penelitian Kualitatif. Bandung: PT. Remaja Rosdakarya.

[18] Ng, dkk. 2015. On Building Social Capital for Islamic Finance. International Journal of Islamic and Middle Eastern Finance Management, hal. 2-19. 
[19] Putnam, Robert D. 1993. The Prosperous Community: Social Capital and Public Life. The American Prospect.

[20] Razmi, dkk. 2013. A Study of The Effect of Social Capital on Human Development in Islamic Countries. Atlantic Review of Economics.

[21] Sanrego, Yulizar D. dan Taufik. 2016. Fiqih Tamkin (Fiqih Pemberdayaan). Jakarta: Qisthi Press.

[22] Setianto. 2015. Peran Masjid Dalam Pemberdayaan Sosial Ekonomi (Studi Kasus pada Masjid At-Taqwa Simorejo Surabaya). Surabaya: Universitas Airlangga. Skripsi Tidak Dipublikasikan.
[23] Susapto. 2013. Peranan Masjid Jogokariyan dalam Memberdayakan Masyarakat di Bidang Keagamaan, Pendidikan, dan Ekonomi. Surakarta: Tesis Universitas Muhammadiyah Surakarta

[24] Wahyuningsih. 2016. Pengaruh Input Produksi Wakaf Berupa Modal dan Tenaga Kerja Terhadap Produktivitas Aset Wakaf Pada Lembaga Wakaf Produktif Yayasan Badan Wakaf Sultan Agung Semarang. Surabaya: Universitas Airlangga. Skripsi Tdak Dipublikasikan.

[25] Yin, Robert K.1996. Studi Kasus: Desain dan Metode. Jakarta: PT Raja Grafindo Persada. Penerjemah: Djauzi Mudzakir. 